\title{
Factors Affecting the University Preferences of Students: A Case of Kafkas University
}

\author{
Ali Caglar Gulluce ${ }^{*}$, Tuncer Yilmaz², Erdogan Kaygin² \\ ${ }^{1}$ Ataturk University, Erzurum, Turkey \\ ${ }^{2}$ Kafkas University, Kars, Turkey \\ Email: *alichaglar@yahoo.com
}

Received 25 January 2016; accepted 28 March 2016; published 31 March 2016

Copyright (C) 2016 by authors and Scientific Research Publishing Inc.

This work is licensed under the Creative Commons Attribution International License (CC BY).

http://creativecommons.org/licenses/by/4.0/

(c) (i) Open Access

\begin{abstract}
University preference is an important subject in that it is effective in the future lives of the students and for the universities to know the factors that are affecting the preferences of the students. Based on this importance, the factors that the students considered while making decision were investigated within the study. For this purpose, survey was applied to the students studying in the Faculty of Economics and Administrative Sciences of Kafkas University in 2013-2014 education term. 309 of the surveys obtained from the departments of administration, economics, and public administration were evaluated. According to the result of the factor analysis carried out, six dimensions consisting of prestige, opportunity, campus, knowledge, location, and economy were obtained. Besides, it was established that these factors differ in demographic properties.
\end{abstract}

\section{Keywords}

University Choice, Preference, Faculty of Economics and Administrative Sciences, Prestige, Economy, Location

\section{Introduction}

Making a choice describes the set of works or the procedure that has a determined starting point and in which various works, activities, and thoughts follow each other starting from this point, and that ends with the making of a choice [1]. Decision describes a result and a choice. For this reason, making a choice means choosing one of the alternatives and giving up the other alternatives.

Choosing a department in an academic way is not a decision as easy as it is thought to be. This decision is much more difficult when it is made in early ages. The result of this decision made is also a determiner of the

${ }^{*}$ Corresponding Author.

How to cite this paper: Gulluce, A.C., Yilmaz, T. and Kaygin, E. (2016) Factors Affecting the University Preferences of Students: A Case of Kafkas University. American Journal of Industrial and Business Management, 6, 357-372.

http://dx.doi.org/10.4236/ajibm.2016.63032 
academic success [2]. According to Carnegie, for a lot of young people, the decision of entering university is the most important decision that will affect their own lives. This decision is important in terms of making and shaping person's life for the next years [3]. When the fact that there are a lot of factors affecting such an important decision and a choice is also taken into consideration, the situation becomes more difficult.

It can be said that a more prestigious university, a university in which he/she can enter the department that s/he wants, a university close to her/his place of residence, a university in a city, in which the transportation is easy, and a lot of other factors are effective in university preference. In addition to these factors and suchlike these that affect entering a university desired, the number of universities in our country is also affecting the students' entering the universities they desire.

By the year 2014, there are 198 universities in total that are active in Turkey. 125 of these universities are public universities and 73 of these universities are foundation universities [4]. Faculties of Economics and Administrative Sciences (or faculty of administration, faculty of economics, faculty of political sciences) are located in most of both public and foundation universities. The basic purpose of the departments in the Faculties of Economics and Administrative Sciences is to raise socially beneficial people that will meet the need for administrators and qualified personnel. Faculty of Economics and Administrative Sciences is present in almost all of the universities in Turkey. In some universities, it gives education only as the Faculty of Political Sciences, the Faculty of Administration, or the Faculty of Economics.

The increase of the number of universities in our country, the idea of reaching the point that was reached by the well-established universities, and the presence of the universities that were founded later and had obtained very good positions in a short time forced the universities to compete with each other. One of the important reasons for this is that it is important to be chosen by the students with the desired qualities besides the problem of filling the capacity for the universities. To provide this, the universities are making an effort in order to rearrange their structures and operations and be more innovative.

The 10 most enterprising and innovative universities of our country are determined with the enterprising and innovative university index, prepared by Scientific and Technical Research Institution of Turkey every year since 2012. With the enterprising and innovative university index, universities were put in an order according to 23 indicators under scientific and technological research competence, intellectual property pool, cooperation and interaction, culture of entrepreneurship and innovativeness and economic contribution and commercialization extents. In this order, Middle East Technical University is in the first place and Sabanci University, Boğaziçi University, Bilkent University, Koç University, Özyeğin University, Istanbul Technical University, TOBB ETU, İzmir High Technology Institute, and Selçuk University follow it respectively [5].

In this study, it was aimed to determine the factors affecting university preference. For this purpose, a survey was applied to the students of the Faculty of Economics and Administrative Sciences of Kars Kafkas University.

\section{Factors Affecting University Preference}

In the literature, the acceptance problem of the student is evaluated as two-sided. According to this, while candidate students are first deciding to which university they are going to apply, the universities will determine who they will accept. The application procedure can be evaluated from three different aspects. First of all, the candidate students are trying to maximize their human capital. Secondly, the universities are trying to increase the human capital of their own graduates. And thirdly, the optimal realization of the social well-being is related to the acceptance of the social well-being function [6].

Especially the scientific studies, carried out in the recent years have shown that demographical and personal factors play a big role in academic career choices. These demographic factors include occupations and education levels of the parents, socio-economic status, sex, and age of the students. Personal factors are their general talent levels, cultural backgrounds, values and principles, their respect for themselves, their self-sufficiency, their interests, and their personalities and they are among the factors that determine the branch that they are going to choose in the university [6].

Moreover, according to the studies carried on by career consultants related to this subject and the psychologists that are experts in the occupational area, the occupational interests of the individuals have an important place in academic area Choice [7].

According to Akar [8], a large number of variables are effective in the university choices of the students. The most important variables are; the geographical location of the university, the social opportunities of the city, closeness to the job opportunities after graduation, closeness to the place that the person lives or works or her/his 
parents live, quality and quantity of the scientific publications of the instructors, and their positive reputation in terms of public opinion. It can be said that there are choices such as the quality of the education, the reputation of the university as a prestigious institution in the public, economic conditions, a campus that is continuously alive with various social and cultural activities, accommodation opportunities, various academic and financial help opportunities, various social groups such as family and friends, sex, and guidance in high school education.

Lastly, the importance of the higher education institutions that are the driving force of science in the world increases day by day. One of the basic reasons for this is the rapid growth and the increasing quality of knowledge. The production, processing, and application of this knowledge that gets concentrated in terms of quantity and quality requires more expertise. It does not seem very likely that the expertise can still be gained with mentor system or the occupational education that is taken at the level of high school. The fact that this concentrated knowledge can only be given at the level of higher education also increases the demand for higher education institutes. Knowing which factors affect the university choices of students in passing to university will be helpful for the universities to get to know themselves and reconstruct themselves, if necessary [9].

The hypotheses that are developed by taking the studies that were previously carried out about the subject into consideration are as follows.

$\mathbf{H}_{\mathbf{1}}$ : The university choices of the students differ significantly according to their sex.

$\mathbf{H}_{2}$ : The university choices of the students differ significantly according to their father's occupation.

$\mathbf{H}_{3}$ : The university choices of the students differ significantly according to their family's monthly income.

$\mathbf{H}_{4}$ : The university choices of the students differ significantly according to their own monthly expenses. from.

$\mathbf{H}_{5}$ : The university choices of the students differ significantly according to the geographical region they come

$\mathbf{H}_{\mathbf{6}}$ : The university choices of the students differ significantly according to their families' place of residence.

$\mathbf{H}_{7}$ : The university choices of the students differ significantly according to their places of residence in the city they study.

\section{The Methodology of the Research}

\subsection{The Purpose of the Research}

The basic purpose of this research consists of the determination of the factors that affects university choices. In relation to this main purpose, the study also concentrates on the fact that whether the factors that affect the university choices of the Faculty of Economics and Administrative Sciences exhibit differences according to the sex, the income level of the families, the geographical region of the place of residence of the families, and the place of residence of the student.

\subsection{The Importance of the Research}

The entrance of students to the universities happens in different ways in different countries of the world. Entering university by passing some certain exams and being successful at the end of this is an important issue for every country. Because, entering the desired university and the desired department will make it easier to be successful and at the end of this, the individual will have the chance to serve her/his country as a qualified workforce [10].

Today's students can be tomorrow's leaders and elites in every area of the society, who determine various politics and make decisions that can affect and change our world [11]. The role of university education and experience in the students' becoming tomorrow's elites and ensuring their continuity of social development can never be disregarded. Because, university education and experience makes it easier for the individuals to be raised as cultured, responsible, and talented citizens in personal terms. In social terms, university education and experience makes the transmission and renewal of knowledge, ideas, talents, customs-conventions and behavior patterns possible. From the perspective of maintaining continuous development and change, university education and experience can re-shape and strengthen the behaviors and the level of consciousness of the university students and sets them as good examples for the society [12].

\subsection{The Scope and the Method of the Research}

The main subject of this study consists of the students who take education in the Faculty of Economics and Administrative Sciences of Kafkas University in 2013-2014 education year. All of the statistical analyses in the 
study were carried out with SPSS. 18 program in 95\% confidence interval and by presupposing a 5\% error. 450 surveys were distributed to the students in total and 417 of these surveys returned. The surveys that were filled out erroneously and incompletely were left out and the remaining 309 surveys were evaluated.

Survey form was facilitated in the research as data collecting method. The survey consists of two parts. There are the questions prepared by Akar (2012) in the first part of the survey. There are 30 questions that were prepared with quinary Likert scale directed towards the factors affecting the university choices of the students in this part. In the scope of the scale, the choices related to each expression consist of questions that are prepared as (1) I don't agree at all, (2) I don't agree, (3) I'm not sure, (4) I agree, (5) I definitely agree. In the second part of the survey, there are questions directed towards determining the demographical characteristics.

\subsection{Confidence Analysis Results}

The confidence analyses that were used in the research were carried out by calculating internal consistence Cronbach Alpha multipliers. Confidence is an indicator of the stability of the measurement values that are obtained in the measurements repeated with a measurement device. Cronbach's Alpha multiplier is a weighted standard change average that is found by comparing the sum of the variances of the $\mathrm{k}$ terms in the scale with the general variance [13]. The confidences of all of the analyses that were carried out in this study were measured with Cronbach's Alpha internal consistence multiplier. The multipliers obtained from the analyses including all of the questions and the questions belonging to each of the six factors are in Table 1.

If Cronbach's Alpha confidence value is between 0.00 and 0.40 , the scale is not confidential. If it is between 0.40 and 0.60 , the confidence of the scale is low. If it is between 0.60 and 0.80 , the scale is very confidential. If it is between 0.80 and 1.00, there is a high level of confidence. Generally, a Cronbach's Alpha multiplier of 0.6 and above shows that there is an acceptable consistency [14]. Based on this, it is possible to say that all of the analyses in the study are confidential by looking at Cronbach’s Alpha values in Table 1.

\section{The Findings of the Research}

\subsection{Findings Related to the Research Sample}

As can be seen by looking at Table 2, 43\% of the students who have participated in the research are men and $57 \%$ of them are women. $12 \%$ of their fathers are civil servants, $16 \%$ of them are workers, $15 \%$ of them are storekeepers, $17 \%$ of them are farmers, $15 \%$ of them have their independent businesses, $20 \%$ of them are retired, and $5 \%$ of them are unemployed. $12 \%$ of the families of the students who have participated in the survey have a monthly income of $500 \mathrm{TL}, 18 \%$ of them have an income of $501-1000 \mathrm{TL}, 27 \%$ of them have an income of 1001 - 1500 TL, 15\% of them have an income of 1501 - 2000 TL, 14\% of them have an income of $2000-3000$ TL, and the remaining $14 \%$ of them have an income above $3000 \mathrm{TL}$. The monthly expenses of $8 \%$ of the students is below $200 \mathrm{TL}$, that of $25 \%$ of them is $201-300 \mathrm{TL}$, that of $37 \%$ of them is $301-500 \mathrm{TL}$, that of $17 \%$ of

Table 1. Confidence analysis results of the scale.
\begin{tabular}{ccc} 
Factors & Cronbach's alpha \\
\hline Scale in general & 0.896 \\
Prestige & 0.813 \\
Opportunity & 0.759 \\
Campus & 0.785 \\
Knowledge & 0.742 \\
Location & 0.812 \\
Economy & 0.776 \\
\hline
\end{tabular}


Table 2. Demographical properties of the students who participated in the survey.

\begin{tabular}{|c|c|c|c|}
\hline Demographic Factor & Category & Number (N) & Percentage (\%) \\
\hline \multirow{2}{*}{ Sex } & 1- Male & 133 & 43 \\
\hline & 2- Female & 176 & 57 \\
\hline \multirow{7}{*}{ Profession of father } & 1- Civil servant & 38 & 12 \\
\hline & 2- Worker & 48 & 16 \\
\hline & 3- Storekeepers & 45 & 15 \\
\hline & 4- Farmers & 53 & 17 \\
\hline & 5- Independent business & 47 & 15 \\
\hline & 6- Retired & 62 & 20 \\
\hline & 7- Unemployed & 16 & 5 \\
\hline \multirow{6}{*}{ Monthly income (TL) } & $1-500$ & 38 & 12 \\
\hline & 2- $501-1000$ & 57 & 18 \\
\hline & 3- $1001-1500$ & 84 & 27 \\
\hline & 4- $1501-2000$ & 48 & 15 \\
\hline & 5- $2000-3000$ & 44 & 14 \\
\hline & 6- 3000 and over & 38 & 14 \\
\hline \multirow{7}{*}{ Monthly expense (TL) } & 1- 200 and below & 25 & 8 \\
\hline & $2-201-300$ & 77 & 25 \\
\hline & 3- $301-500$ & 115 & 37 \\
\hline & 4- $501-750$ & 54 & 17 \\
\hline & 5- $751-900$ & 18 & 6 \\
\hline & 6- $901-1000$ & 6 & 2 \\
\hline & 7- 1000 and over & 14 & 5 \\
\hline \multirow{7}{*}{ Geographical location of where students come } & 1- Marmara & 37 & 12 \\
\hline & 2- Central Anatolia & 17 & 6 \\
\hline & 3- Aegean & 22 & 7 \\
\hline & 4- Black Sea & 27 & 9 \\
\hline & 5- East Anatolia & 130 & 42 \\
\hline & 6- Southeast Anatolia & 53 & 17 \\
\hline & 7- Mediterranean & 23 & 7 \\
\hline \multirow{5}{*}{ Living county of the family } & 1- Village & - & - \\
\hline & 2- Town & 81 & 26 \\
\hline & 3- County & 8 & 6 \\
\hline & 4- City & 77 & 25 \\
\hline & 5- Metropolitan municipality & 143 & 43 \\
\hline \multirow{4}{*}{ Places of residence in the cities in which they study } & 1- Student apartments & 125 & 40 \\
\hline & 2- With their families & 54 & 17 \\
\hline & 3- Government dormitories & 89 & 29 \\
\hline & 4- Private dormitories/pensions & 41 & 14 \\
\hline
\end{tabular}

them is $501-750 \mathrm{TL}$, that of $6 \%$ of them is $751-900 \mathrm{TL}$, that of $2 \%$ of them is $901-1000 \mathrm{TL}$, and that of $5 \%$ of them is above 1000 TL. $12 \%$ of the students who have participated in the research come from Marmara region, $6 \%$ of them come from Middle Anatolian region, $7 \%$ of them come from Aegean region, $9 \%$ of them come from Black Sea region, $42 \%$ of them come from Eastern Anatolian region, $17 \%$ of them come from Southeastern Anatolian region, and $7 \%$ of them come from Mediterranean region. In terms of their families’ places of residence, $26 \%$ of them are living in towns, $6 \%$ of them are living in counties, $25 \%$ of them are living in cities, and $43 \%$ of them are living in metropolitan municipalities. In terms of their places of residence in the cities in which they study, $40 \%$ of them are staying in student apartments, $17 \%$ of them are staying with their families, $29 \%$ of them are staying in government dormitories, and $14 \%$ of them are staying in private dormitories or pensions.

\subsection{Factor Analysis Results}

Factor analysis is a widely-used multiple-variable statistical analysis technique that brings more than one variables that are related to each other and turns them into a little number of significant factors. Kaiser-MeyerOl-kin (KMO) test was carried out in order to analyze the validity of the data obtained in factor analysis. KMO test is used in testing the size of the correlation multipliers that are observed in factor analysis and the size of the partial correlation multipliers. KMO value must be larger than 0.50; in the case that it is smaller, factor analysis is not continued. The following interpretations are made about the KMO values; below 0.50 "not acceptable", 


\section{A. C. Gulluce et al.}

0.50 “poor”, 0.60 “fair”, 0.70 "good”, 0.80 "very good”, and 0.90 “excellent”. In the case that it turns out to be below 0.50, more surveys must be subjected to the procedure (Kalayci, 2010: p. 322).

In the factor analysis that was carried out, KMO ratio was calculated as 0.883 and Bartlett's test value was calculated as $608(\mathrm{p}<0.000)$. The fact that these multipliers turn out to be significant shows that the data is suitable for factor analysis. At the end of the analysis, scale terms were collected under six factors that explain $59.516 \%$ of the total variance. This variance ratio obtained is a ratio that is accepted as appropriate in the studies.

The results of the factor analysis obtained from this study have come out to be the same as the results of the factor analysis that Akar (2012) has carried out in the study of question. A structure of six factors was obtained in both of the studies and the factors in this research were named with the names that Akar has given in the study of the year 2012. The results obtained from the factor analysis are in Table 3.

Table 3. Factor analysis results of the scale.

\begin{tabular}{|c|c|c|}
\hline Factors & $\begin{array}{l}\text { Factor } \\
\text { loads }\end{array}$ & $\begin{array}{l}\text { Explained } \\
\text { variance (\%) }\end{array}$ \\
\hline Factor 1: Prestige & & 12.168 \\
\hline 1) Profile name and curriculum vitae of the university faculty has been effective for me & 0.510 & \\
\hline 2) Success of the university in KPSS and other examinations has been effective in my preference. & 0.575 & \\
\hline 3) Perceived academic respectability of the university has been effective in my preference. & 0.771 & \\
\hline 4) Brand name of the University has been effective in my preference. & 0.736 & \\
\hline 5) The quality of university education has been effective in my preference. & 0.744 & \\
\hline 6) Finding employment opportunities for graduates of the University has been effective in my preference. & 0.553 & \\
\hline Factor 2: Location & & 8.888 \\
\hline 8) Proximity of the university to my family residence has been effective in my preference & 0.909 & \\
\hline 10) Transportation opportunities of the university to my family residence has been effective in my preference. & 0.905 & \\
\hline $\begin{array}{l}\text { 30) Residence of my family or a relative in the city where the university is located has been effective in my } \\
\text { preference }\end{array}$ & 0.691 & \\
\hline Factor 3: Campus & & 10.068 \\
\hline 11) Physical facilities of the campus (buildings, library, canteen, etc.) has been effective in my preference. & 0.599 & \\
\hline 12) Social facilities of the University (entertainment, sports, etc.) has been effective in my preference. & 0.641 & \\
\hline 13) Being a safe university campus has been effective in my preference & 0.565 & \\
\hline 14) The proximity of university campus to the city center has been effective in my preference & 0.719 & \\
\hline 15) Dormitory, hostel and similar opportunities within the university campus has been effective in my preference & 0.648 & \\
\hline Factor 4: Opportunity & & 10.822 \\
\hline 16) The student exchange program with overseas universities has been effective in my preference & 0.497 & \\
\hline 17) Providing part-time jobs for students has been effective in my preference & 0.607 & \\
\hline 18) The internationally recognized diplomas to graduates of the university have been effective in my preference. & 0.659 & \\
\hline 19) Helping in finding jobs for graduates through the University’s career center has been effective in my preference. & 0.687 & \\
\hline 20) Providing internship opportunities to students of the University has been effective in my preference. & 0.542 & \\
\hline Factor 5: Knowledge & & 8.969 \\
\hline 22) The advice of my friends has been effective in my preference & 0.683 & \\
\hline 23) Magazine, newspaper and information on the Internet about the university has been effective in preference. & 0.726 & \\
\hline 24) The information I obtained from the University’s web page has been effective in my preference & 0.705 & \\
\hline 25) Suggesting/recommendations of my high schoolteachers have been effective in my preferences. & 0.673 & \\
\hline Factor 6: Economy & & 8.602 \\
\hline 26) Having cheap living conditions of the city where the university located has been effective in my preferences & 0.644 & \\
\hline 27) University scholarships and financial assistance such as food preferences has been effective in my preferences & 0.739 & \\
\hline 28) Having government dormitory in the city where the university located has been effective in my preferences & 0.765 & \\
\hline
\end{tabular}


There are some basic statistical data belonging to the factors in Table 4. According to these data that are obtained, it was established that the most deterministic factor in the university choices of students is the location of the university, and it is followed by knowledge, opportunity, prestige, campus and lastly economy factor.

\subsection{Mann-Whitney U Test Results}

Kolmogorov-Smirnov normality test was applied to all of the factors in 95\% confidence interval before doing Mann-Whitney U and Kruskal-Wallis tests and p (Sig.) values have come out to be less than 0.05 for all of the variables. For this reason, the data does not show normal distribution. For this reason, non-parametric tests were preferred in the analyses.

Mann-Whitney U test was used for the establishment of the differences between two independent groups in the study. This test is the non-parametric alternative for the t-tests that are applied for independent samples. Mann-Whitney U test compares the medians of the groups. In this way, it evaluates whether the order between the two groups is different or not [15]. Analyses that are carried out and hypotheses that are developed in this study and the tables and comments belonging to the analyses are below.

$\mathrm{P}$ values of the factors are considered in Mann-Whitney $\mathrm{U}$ test. It is evaluated as there is a significant difference between the averages if the $\mathrm{p}$ value is less than 0.05 and as there is not a significant difference if the $\mathrm{p}$ value is above 0.05 . Based on this, whereas a statistically significant difference is detected between the averages of the sexes in location and opportunity factors, a significant difference was not detected in the other factors when the $\mathrm{p}$ values of the factors in Table 5 are considered. For this reason, whereas $\mathrm{H}_{1}$ hypothesis is accepted in location and opportunity factors, this hypothesis was rejected in the other factors.

Besides, when the order average values are considered, prestige factor was the most deterministic factor in university choices of female students. And it is followed by campus, opportunity, knowledge, and economy factors respectively. Whereas prestige factor is the first factor in the choices of male students, it is followed by opportunity, campus, knowledge, and economy factors respectively.

\subsection{Kruskal-Wallis Test Results}

Kruskal-Wallis or Kruskal-Wallis $\mathrm{H}$ test makes it possible to compare more than two groups by looking at their ordered averages. This test is the non-parametric equivalent of Anova Test. By using this test, it was desired to determine whether there is a difference between the averages of demographic characteristics and whether this difference is statistically significant, if it is present.

The most important values that need to be taken into consideration in Kruskal-Wallis tests are Chi-Square and $\mathrm{p}$ (Asymp. Sig) values. It is evaluated as there is a significant difference between the variables if the p value is less than 0.05 and as there is not a significant difference if the $\mathrm{p}$ value is above 0.05 .

When Table 6, which includes the statistical results related to the occupation of students' fathers is examined, whereas the difference between the averages was found to be significant in location factor, it was not found to be significant in the other factors. In this case, whereas $\mathrm{H}_{2}$ hypothesis was accepted for location factor, it was rejected in the other factors.

When the order averages of the groups in the table are taken into consideration, prestige factor was preferred more by the students whose fathers are unemployed; knowledge, campus, and opportunity factors were preferred more by the students whose fathers are retired, location factor was preferred more by the students whose fathers are farmers, economy factor was preferred more by the students whose fathers have their own independent businesses.

\section{Table 4. Some basic statistics belonging to the factors.}

\begin{tabular}{|c|c|c|c|c|c|c|}
\hline Statistics & Prestige & Knowledge & Campus & Location & Opportunity & Economy \\
\hline $\mathrm{N}$ & 1854 & 1236 & 1545 & 927 & 1545 & 927 \\
\hline Mean & 2.27 & 2.48 & 2.26 & 2.65 & 2.30 & 2.06 \\
\hline Median & 2.00 & 2.00 & 2.00 & 2.00 & 2.00 & 2.00 \\
\hline $\begin{array}{c}\text { Standard } \\
\text { Deviation }\end{array}$ & 1.196 & 1.339 & 1.265 & 1.584 & 1.243 & 1.266 \\
\hline Variance & 1.431 & 1.793 & 1.601 & 2.507 & 1.544 & 1.603 \\
\hline
\end{tabular}


Table 5. Mann-Whitney U test results related to sex characteristics.

\begin{tabular}{|c|c|c|c|c|c|c|}
\hline Factors & Sex & $\mathrm{N}$ & Mean Rank & Mean Total & $\mathrm{Z}$ & $\mathrm{P}$ \\
\hline \multirow{3}{*}{ Prestige } & Male & 798 & 912.90 & $728,494.00$ & & \\
\hline & Female & 1056 & 938.53 & $991,091.00$ & -1.061 & 0.289 \\
\hline & Total & 1854 & & & & \\
\hline \multirow{3}{*}{ Knowledge } & Male & 532 & 607.72 & $323,308.50$ & & \\
\hline & Female & 704 & 626.64 & $441,157.50$ & -0.953 & 0.341 \\
\hline & Total & 1236 & & & & \\
\hline \multirow{3}{*}{ Campus } & Male & 665 & 782.71 & $520,500.00$ & & \\
\hline & Female & 880 & 765.66 & $673,785.00$ & -0.774 & 0.439 \\
\hline & Total & 1545 & & & & \\
\hline \multirow{3}{*}{ Location } & Male & 399 & 437.31 & $174,485.50$ & & \\
\hline & Female & 528 & 484.17 & $255,642.50$ & -2.734 & 0.006 \\
\hline & Total & 927 & & & & \\
\hline \multirow{3}{*}{ Opportunity } & Male & 665 & 797.85 & $530,569.50$ & & \\
\hline & Female & 880 & 754.22 & $663,715.50$ & -1.975 & 0.048 \\
\hline & Total & 1545 & & & & \\
\hline \multirow{3}{*}{ Economy } & Male & 399 & 472.89 & $188,684.00$ & & \\
\hline & Female & 528 & 457.28 & $241,444.00$ & -0.940 & 0.347 \\
\hline & Total & 927 & & & & \\
\hline
\end{tabular}

When the findings in Table 7 are examined, whereas a significant difference is found between the averages of the variables in knowledge and opportunity factors, a significant difference was not found in the other factors. According to this result obtained, whereas $\mathrm{H}_{3}$ hypothesis was accepted in knowledge and opportunity factors, it was rejected in the other factors.

Besides, when the order averages in the table are considered, prestige and knowledge factors were preferred more by the students whose families' income is between 1001 - 1500 TL, campus factor was preferred more by the students whose families' income is above $3000 \mathrm{TL}$, location factor was preferred more by the students whose families' income is between 2000 - 3000, opportunity and economy factors were preferred more by the students whose families' income is $500 \mathrm{TL}$.

When the p values in Table 8, which includes the results about the monthly expenses of the student, are considered, the difference between the averages of the variables have come out to be statistically significant in all of the factors other than opportunity factor. According to this result, whereas $\mathrm{H}_{4}$ hypothesis was rejected for opportunity factor, it was accepted in the other factors.

When the order averages of the variables in this table are considered, it was observed that prestige, campus, location, and opportunity factors were preferred more by the students whose monthly expenses are between 751 - 900 TL, knowledge factor was preferred more by the students whose monthly expenses are between 901 - 1000 TL, economy factor was preferred more by the students whose monthly expenses are between 501 - $750 \mathrm{TL}$.

The results obtained in the analysis carried out about the geographical region that the student comes from are in Table 9. According to these results, whereas the relationship between the averages of the variables in prestige, campus, location, and opportunity comes out to be statistically significant, this relationship was not found to be statistically significant in knowledge and economy factor. Based on this result, whereas $\mathrm{H}_{5}$ hypothesis was accepted in prestige, campus, location, and opportunity factors, it was rejected in the other factors.

When the order averages of the variables in the table are considered, it is found that prestige, campus, and opportunity factors are preferred more by the students coming from Aegean region, knowledge factor is preferred more by the students coming from Black Sea region, location factor is preferred more by the students coming from Eastern Anatolian region, economy factor was preferred more by the students coming from Middle Anatolian region. 
A. C. Gulluce et al.

Table 6. Kruskal-Wallis test results related to the occupation of the father.

\begin{tabular}{|c|c|c|c|c|c|c|}
\hline Factors & Profession of father & $\mathrm{N}$ & Mean & $\chi^{2}$ & Degrees of freedom (df) & Significance level (p) \\
\hline \multirow{8}{*}{ Prestige } & Civil servant & 234 & 935.94 & \multirow{8}{*}{4.128} & \multirow{7}{*}{6} & \multirow{7}{*}{0.659} \\
\hline & Worker & 294 & 954.39 & & & \\
\hline & Storekeepers & 276 & 936.45 & & & \\
\hline & Farmers & 324 & 905.47 & & & \\
\hline & Independent business & 288 & 924.56 & & & \\
\hline & Retired & 372 & 901.44 & & & \\
\hline & Unemployed & 66 & 1008.29 & & & \\
\hline & Total & 1854 & & & \multirow{9}{*}{6} & \multirow{9}{*}{0.168} \\
\hline \multirow{8}{*}{ Knowledge } & Civil servant & 156 & 587.58 & \multirow{8}{*}{9.104} & & \\
\hline & Worker & 196 & 609.96 & & & \\
\hline & Storekeepers & 184 & 609.01 & & & \\
\hline & Farmers & 216 & 597.38 & & & \\
\hline & Independent Meslek & 192 & 607.29 & & & \\
\hline & Retired & 248 & 673.33 & & & \\
\hline & Unemployed & 44 & 649.38 & & & \\
\hline & Total & 1236 & & & & \\
\hline \multirow{8}{*}{ Campus } & Civil servant & 195 & 770.63 & \multirow{8}{*}{3.974} & \multirow{7}{*}{6} & \multirow{7}{*}{0.680} \\
\hline & Worker & 245 & 740.58 & & & \\
\hline & Storekeepers & 230 & 779.99 & & & \\
\hline & Farmers & 270 & 754.8 & & & \\
\hline & Independent business & 240 & 794.94 & & & \\
\hline & Retired & 310 & 798.95 & & & \\
\hline & Unemployed & 55 & 744 & & & \\
\hline & Total & 1545 & & & \multirow{9}{*}{6} & \multirow{9}{*}{0.018} \\
\hline \multirow{8}{*}{ Location } & Civil Servant & 117 & 466.77 & \multirow{8}{*}{15.371} & & \\
\hline & Worker & 147 & 418.06 & & & \\
\hline & Storekeepers & 138 & 475.73 & & & \\
\hline & Farmers & 162 & 508.11 & & & \\
\hline & Independent business & 144 & 431.59 & & & \\
\hline & Retired & 186 & 487.54 & & & \\
\hline & Unemployed & 33 & 401.97 & & & \\
\hline & Total & 927 & & & & \\
\hline \multirow{8}{*}{ Opportunity } & Civil Servant & 195 & 777.69 & \multirow{8}{*}{5.121} & \multirow{8}{*}{6} & \multirow{8}{*}{0.528} \\
\hline & Worker & 245 & 742.19 & & & \\
\hline & Storekeepers & 230 & 740.88 & & & \\
\hline & Farmers & 270 & 786.43 & & & \\
\hline & Independent business & 240 & 780.11 & & & \\
\hline & Retired & 310 & 786.84 & & & \\
\hline & Unemployed & 55 & 853 & & & \\
\hline & Total & 1545 & & & & \\
\hline \multirow{8}{*}{ Economy } & Civil servant & 117 & 477.69 & & & \\
\hline & Worker & 147 & 423.4 & & & \\
\hline & Storekeepers & 138 & 448.7 & & & \\
\hline & Farmers & 162 & 472.32 & 7225 & 6 & 0301 \\
\hline & Independent business & 144 & 491.27 & 1.220 & 0 & 0.301 \\
\hline & Retired & 186 & 474.55 & & & \\
\hline & Unemployed & 33 & 440.94 & & & \\
\hline & Total & 927 & & & & \\
\hline
\end{tabular}


Table 7. Kruskal-Wallis test results related to the monthly income of the family.

\begin{tabular}{|c|c|c|c|c|c|c|}
\hline Factors & Monthly income (TL) & $\mathrm{N}$ & Mean rank & $\chi^{2}$ & Degrees of freedom (df) & Significance level (p) \\
\hline \multirow{7}{*}{ Prestige } & 500 & 234 & 893.26 & \multirow{7}{*}{19.931} & \multirow{7}{*}{5} & \multirow{7}{*}{0.001} \\
\hline & $501-1000$ & 336 & 917.02 & & & \\
\hline & $1001-1500$ & 522 & 997.01 & & & \\
\hline & $1501-2000$ & 318 & 853.87 & & & \\
\hline & $2000-3000$ & 276 & 893 & & & \\
\hline & 3000 and over & 168 & 976.23 & & & \\
\hline & Total & 1854 & & & & \\
\hline \multirow{7}{*}{ Knowledge } & 500 & 156 & 595.77 & \multirow{7}{*}{14.250} & \multirow{7}{*}{5} & \multirow{7}{*}{0.014} \\
\hline & $501-1000$ & 224 & 549.38 & & & \\
\hline & $1001-1500$ & 348 & 655.17 & & & \\
\hline & $1501-2000$ & 212 & 634.81 & & & \\
\hline & $2000-3000$ & 184 & 629.58 & & & \\
\hline & 3000 and over & 112 & 625.37 & & & \\
\hline & Total & 1236 & & & & \\
\hline \multirow{7}{*}{ Campus } & 500 & 195 & 746.09 & \multirow{7}{*}{6.603} & \multirow{7}{*}{5} & \multirow{7}{*}{0.252} \\
\hline & $501-1000$ & 280 & 739.39 & & & \\
\hline & $1001-1500$ & 435 & 769.02 & & & \\
\hline & $1501-2000$ & 265 & 811.03 & & & \\
\hline & $2000-3000$ & 230 & 769.48 & & & \\
\hline & 3000 and over & 140 & 823.85 & & & \\
\hline & Total & 1545 & & & & \\
\hline \multirow{7}{*}{ Location } & 500 & 117 & 458.19 & \multirow{7}{*}{5.974} & \multirow{7}{*}{5} & \multirow{7}{*}{0.309} \\
\hline & $501-1000$ & 168 & 432.18 & & & \\
\hline & $1001-1500$ & 261 & 475.76 & & & \\
\hline & $1501-2000$ & 159 & 454.49 & & & \\
\hline & $2000-3000$ & 138 & 499.35 & & & \\
\hline & 3000 and over & 84 & 459.11 & & & \\
\hline & Total & 927 & & & & \\
\hline \multirow{7}{*}{ Opportunity } & 500 & 195 & 820.75 & \multirow{7}{*}{11.202} & \multirow{7}{*}{5} & \multirow{7}{*}{0.048} \\
\hline & $501-1000$ & 280 & 725.91 & & & \\
\hline & $1001-1500$ & 435 & 806.49 & & & \\
\hline & $1501-2000$ & 265 & 729.09 & & & \\
\hline & $2000-3000$ & 230 & 777.97 & & & \\
\hline & 3000 and over & 140 & 771.55 & & & \\
\hline & Total & 1545 & & & & \\
\hline \multirow{7}{*}{ Economy } & 500 & 117 & 490.88 & \multirow{7}{*}{4.647} & \multirow{7}{*}{5} & \multirow{7}{*}{0.460} \\
\hline & $501-1000$ & 168 & 444.61 & & & \\
\hline & $1001-1500$ & 261 & 470.97 & & & \\
\hline & $1501-2000$ & 159 & 480.1 & & & \\
\hline & $2000-3000$ & 138 & 449.39 & & & \\
\hline & 3000 and over & 84 & 437.2 & & & \\
\hline & Total & 927 & & & & \\
\hline
\end{tabular}


Table 8. Kruskal-Wallis test results related to her/his own monthly expenses.

\begin{tabular}{|c|c|c|c|c|c|c|}
\hline Factors & $\begin{array}{l}\text { Personal monthly } \\
\text { expense (TL) }\end{array}$ & $\mathrm{N}$ & Mean rank & $\chi^{2}$ & Degrees of freedom (df) & Significance level (p) \\
\hline \multirow{8}{*}{ Prestige } & 200 and below & 150 & 965.47 & \multirow{8}{*}{19.243} & \multirow{8}{*}{6} & \multirow{8}{*}{0.004} \\
\hline & $201-300$ & 462 & 857.65 & & & \\
\hline & $301-500$ & 696 & 961.04 & & & \\
\hline & $501-750$ & 330 & 889.46 & & & \\
\hline & $751-900$ & 114 & 1029.2 & & & \\
\hline & $901-1000$ & 36 & 949.69 & & & \\
\hline & 1000 and over & 66 & 978.86 & & & \\
\hline & Total & 1854 & & & & \\
\hline \multirow{8}{*}{ Knowledge } & 200 and below & 100 & 634.32 & \multirow{8}{*}{15.642} & \multirow{8}{*}{6} & \multirow{8}{*}{0.016} \\
\hline & $201-300$ & 308 & 575.56 & & & \\
\hline & $301-500$ & 464 & 625.05 & & & \\
\hline & $501-750$ & 220 & 608.08 & & & \\
\hline & $751-900$ & 76 & 723.11 & & & \\
\hline & $901-1000$ & 24 & 747.67 & & & \\
\hline & 1000 and over & 44 & 615.01 & & & \\
\hline & Total & 1236 & & & & \\
\hline \multirow{8}{*}{ Campus } & 200 and below & 125 & 776.45 & \multirow{8}{*}{20.015} & \multirow{8}{*}{6} & \multirow{8}{*}{0.003} \\
\hline & $201-300$ & 385 & 712.98 & & & \\
\hline & $301-500$ & 580 & 797.39 & & & \\
\hline & $501-750$ & 275 & 758.3 & & & \\
\hline & 751 - 900 & 95 & 912.35 & & & \\
\hline & $901-1000$ & 30 & 738.57 & & & \\
\hline & 1000 and over & 55 & 779.65 & & & \\
\hline & Total & 1545 & & & & \\
\hline \multirow{8}{*}{ Location } & 200 and below & 75 & 435.88 & \multirow{8}{*}{21.758} & \multirow{8}{*}{6} & \multirow{8}{*}{0.001} \\
\hline & $201-300$ & 231 & 498.18 & & & \\
\hline & $301-500$ & 348 & 453.36 & & & \\
\hline & $501-750$ & 165 & 481.48 & & & \\
\hline & 751 - 900 & 57 & 499.61 & & & \\
\hline & $901-1000$ & 18 & 317.94 & & & \\
\hline & 1000 and over & 33 & 331.67 & & & \\
\hline & Total & 927 & & & & \\
\hline \multirow{8}{*}{ Opportunity } & 200 and below & 125 & 770.04 & \multirow{8}{*}{12.281} & \multirow{8}{*}{6} & \multirow{8}{*}{0.056} \\
\hline & $201-300$ & 385 & 720.11 & & & \\
\hline & $301-500$ & 580 & 776.56 & & & \\
\hline & $501-750$ & 275 & 816.09 & & & \\
\hline & 751 - 900 & 95 & 844.17 & & & \\
\hline & $901-1000$ & 30 & 838.07 & & & \\
\hline & 1000 and over & 55 & 738.55 & & & \\
\hline & Total & 1545 & & & & \\
\hline \multirow{8}{*}{ Economy } & 200 and below & 75 & 450.91 & & & \\
\hline & $201-300$ & 231 & 420.76 & & & \\
\hline & $301-500$ & 348 & 480.78 & & & \\
\hline & $501-750$ & 165 & 500.45 & 13.621 & 6 & 0.034 \\
\hline & 751 - 900 & 57 & 472.56 & & & \\
\hline & 901 - 1000 & 18 & 479.92 & & & \\
\hline & 1000 and over & 33 & 413.77 & & & \\
\hline & Total & 927 & & & & \\
\hline
\end{tabular}


Table 9. Kruskal-Wallis test results related to the geographical region that s/he comes from.

\begin{tabular}{|c|c|c|c|c|c|c|}
\hline Factors & Region & $\mathrm{N}$ & Mean rank & $\chi^{2}$ & Degrees of freedom (df) & Significance level (p) \\
\hline \multirow{8}{*}{ Prestige } & Marmara & 222 & 975.85 & \multirow{8}{*}{28.572} & \multirow{8}{*}{6} & \multirow{8}{*}{0.000} \\
\hline & Central Anatolia & 102 & 921.73 & & & \\
\hline & Eagean & 132 & 1026.48 & & & \\
\hline & Black sea & 162 & 1013.94 & & & \\
\hline & East Anatolia & 786 & 870.5 & & & \\
\hline & Southeast Anatolia & 324 & 984.55 & & & \\
\hline & Mediterranean & 126 & 841.04 & & & \\
\hline & Total & 1854 & & & & \\
\hline \multirow{8}{*}{ Knowledge } & Marmara & 148 & 652.63 & \multirow{8}{*}{5.071} & \multirow{8}{*}{6} & \multirow{8}{*}{0.535} \\
\hline & Central Anatolia & 68 & 622.38 & & & \\
\hline & Eagean & 88 & 617.51 & & & \\
\hline & Black sea & 108 & 665.78 & & & \\
\hline & East Anatolia & 524 & 612.18 & & & \\
\hline & Southeast Anatolia & 216 & 592.32 & & & \\
\hline & Mediterranean & 84 & 602.22 & & & \\
\hline & Total & 1236 & & & & \\
\hline \multirow{8}{*}{ Campus } & Marmara & 185 & 820.65 & \multirow{8}{*}{13.076} & \multirow{8}{*}{6} & \multirow{8}{*}{0.042} \\
\hline & Central Anatolia & 85 & 758.41 & & & \\
\hline & Eagean & 110 & 840.71 & & & \\
\hline & Black sea & 135 & 788.33 & & & \\
\hline & East Anatolia & 655 & 742.96 & & & \\
\hline & Southeast Anatolia & 270 & 809.01 & & & \\
\hline & Mediterranean & 105 & 704.98 & & & \\
\hline & Total & 1545 & & & & \\
\hline \multirow{8}{*}{ Location } & Marmara & 111 & 436.76 & \multirow{8}{*}{169.604} & \multirow{8}{*}{6} & \multirow{8}{*}{0.000} \\
\hline & Central Anatolia & 51 & 401.59 & & & \\
\hline & Eagean & 66 & 374.52 & & & \\
\hline & Black sea & 81 & 363.94 & & & \\
\hline & East Anatolia & 393 & 586.02 & & & \\
\hline & Southeast Anatolia & 162 & 368.19 & & & \\
\hline & Mediterranean & 63 & 270.1 & & & \\
\hline & Total & 927 & & & & \\
\hline \multirow{8}{*}{ Opportunity } & Marmara & 185 & 807.81 & \multirow{8}{*}{22.686} & \multirow{8}{*}{6} & \multirow{8}{*}{0.001} \\
\hline & Central Anatolia & 85 & 783.34 & & & \\
\hline & Eagean & 110 & 898.99 & & & \\
\hline & Black sea & 135 & 801.23 & & & \\
\hline & East Anatolia & 655 & 739.85 & & & \\
\hline & Southeast Anatolia & 270 & 801.78 & & & \\
\hline & Mediterranean & 105 & 667.78 & & & \\
\hline & Total & 1545 & & & & \\
\hline \multirow{8}{*}{ Economy } & Marmara & 111 & 468.14 & & & \\
\hline & Central Anatolia & 51 & 490.25 & & & \\
\hline & Eagean & 66 & 476.6 & & & \\
\hline & Black sea & 81 & 458.1 & 7496 & 6 & 0.277 \\
\hline & East Anatolia & 393 & 468.31 & & & \\
\hline & Southeast Anatolia & 162 & 471.39 & & & \\
\hline & Mediterranean & 63 & 383.97 & & & \\
\hline & Total & 927 & & & & \\
\hline
\end{tabular}


There are Kruskal-Wallis test results about the places of residence of the students' families in Table 10. By these results, it can be said that the relationship between the averages of the variables in all of the factors other than opportunity factor is found to be statistically significant. Looking at the significance levels of the factors in this table, whereas $\mathrm{H}_{6}$ hypothesis was rejected in economy and opportunity factors, this hypothesis was accepted in prestige, knowledge, campus, and location factors.

When the order averages of the variables about the place of residence of the students' families is considered, it was established that a stronger participation was maintained in prestige, knowledge, and opportunity factors by the students whose families are living in counties, in campus factor by the students whose families are living in metropolitan municipalities, in location and economy factors by the students whose families are living in cities that are not metropolitan municipalities.

Table 10. Kruskal-Wallis test results related to the place of residence of her/his family.

\begin{tabular}{|c|c|c|c|c|c|c|}
\hline Factors & Residence of family & $\mathrm{N}$ & Mean rank & $\chi^{2}$ & $\begin{array}{l}\text { Degrees of } \\
\text { freedom (df) }\end{array}$ & Significance level (p) \\
\hline \multirow{6}{*}{ Prestige } & Village & 486 & 916.66 & \multirow{6}{*}{15.669} & \multirow{6}{*}{4} & \multirow{6}{*}{0.003} \\
\hline & Town & 54 & 927.61 & & & \\
\hline & County & 462 & 986.48 & & & \\
\hline & City & 372 & 847.73 & & & \\
\hline & Metropolitan municipality & 480 & 943.53 & & & \\
\hline & Total & 1854 & & & & \\
\hline \multirow{6}{*}{ Knowledge } & Village & 324 & 589.67 & \multirow{6}{*}{13.682} & \multirow{6}{*}{4} & \multirow{6}{*}{0.008} \\
\hline & Town & 36 & 637.42 & & & \\
\hline & County & 308 & 674.86 & & & \\
\hline & City & 248 & 579.77 & & & \\
\hline & Metropolitan municipality & 320 & 621.34 & & & \\
\hline & Total & 1236 & & & & \\
\hline \multirow{6}{*}{ Campus } & Village & 405 & 720.69 & \multirow{6}{*}{9.625} & \multirow{6}{*}{4} & \multirow{6}{*}{0.047} \\
\hline & Town & 45 & 791.13 & & & \\
\hline & County & 385 & 773.82 & & & \\
\hline & City & 310 & 789.31 & & & \\
\hline & Metropolitan municipality & 400 & 810.48 & & & \\
\hline & Total & 1545 & & & & \\
\hline \multirow{6}{*}{ Location } & Village & 243 & 494.4 & \multirow{6}{*}{35.417} & \multirow{6}{*}{4} & \multirow{6}{*}{0.000} \\
\hline & Town & 27 & 471.2 & & & \\
\hline & County & 231 & 425.51 & & & \\
\hline & City & 186 & 540.78 & & & \\
\hline & Metropolitan municipality & 240 & 409.96 & & & \\
\hline & Total & 927 & & & & \\
\hline \multirow{6}{*}{ Opportunity } & Village & 405 & 784.12 & \multirow{6}{*}{8.444} & \multirow{6}{*}{4} & \multirow{6}{*}{0.077} \\
\hline & Town & 45 & 737.02 & & & \\
\hline & County & 385 & 817.03 & & & \\
\hline & City & 310 & 728.45 & & & \\
\hline & Metropolitan municipality & 400 & 757.94 & & & \\
\hline & Total & 1545 & & & & \\
\hline \multirow{6}{*}{ Economy } & Village & 243 & 458.15 & \multirow{6}{*}{1.536} & \multirow{6}{*}{4} & \multirow{6}{*}{0.820} \\
\hline & Town & 27 & 446.57 & & & \\
\hline & County & 231 & 467.41 & & & \\
\hline & City & 186 & 481.59 & & & \\
\hline & Metropolitan municipality & 240 & 454.97 & & & \\
\hline & Total & 927 & & & & \\
\hline
\end{tabular}


The test results about the place of residence of the students in the city that they study in are in Table 11. Considering the $\mathrm{p}$ values in this table, the relationship between the averages of the variables in all of the factors other than knowledge and economy factors was found to be statistically significant. For this reason, whereas $\mathrm{H}_{7}$ hypothesis was rejected in knowledge and economy factors, this hypothesis was accepted in prestige, campus, location, and opportunity factors.

Another result that comes out in the table is the values belonging to the order averages of the groups. Considering these variables, it is possible to say that the students who stay in private dormitories or pensions put more importance into campus and opportunity factors, students who stay in government dormitories put more importance into knowledge and location factors, and the students who stay with their families put more importance into economy factor.

Table 11. Kruskal-Wallis test results related to her/his place of residence in the city that s/he studies in.

\begin{tabular}{|c|c|c|c|c|c|c|}
\hline Factors & Residence that studied in & $\mathrm{N}$ & Mean rank & $\chi^{2}$ & Degrees of freedom (df) & Significance level (p) \\
\hline \multirow{5}{*}{ Prestige } & Student apartments & 750 & 899.54 & \multirow{5}{*}{14.528} & \multirow{5}{*}{3} & \multirow{5}{*}{0.002} \\
\hline & With their families & 324 & 888.54 & & & \\
\hline & Government dormitories & 540 & 943.06 & & & \\
\hline & Private dormitories/pensions & 240 & 1032.45 & & & \\
\hline & Total & 1854 & & & & \\
\hline \multirow{5}{*}{ Knowledge } & Student apartments & 500 & 613.47 & \multirow{5}{*}{5.891} & \multirow{5}{*}{3} & \multirow{5}{*}{0.117} \\
\hline & With their families & 216 & 578.26 & & & \\
\hline & Government dormitories & 360 & 649.31 & & & \\
\hline & Private dormitories/pensions & 160 & 619.23 & & & \\
\hline & Total & 1236 & & & & \\
\hline \multirow{5}{*}{ Campus } & Student apartments & 625 & 753.04 & \multirow{5}{*}{10.977} & \multirow{5}{*}{3} & \multirow{5}{*}{0.012} \\
\hline & With their families & 270 & 816.35 & & & \\
\hline & Government dormitories & 450 & 744.84 & & & \\
\hline & Private dormitories/pensions & 200 & 840.19 & & & \\
\hline & Total & 1545 & & & & \\
\hline \multirow{5}{*}{ Location } & Student apartments & 375 & 409.09 & \multirow{5}{*}{88.473} & \multirow{5}{*}{3} & \multirow{5}{*}{0.000} \\
\hline & With their families & 162 & 628.17 & & & \\
\hline & Government dormitories & 270 & 467.69 & & & \\
\hline & Private dormitories/pensions & 120 & 405.64 & & & \\
\hline & Total & 927 & & & & \\
\hline \multirow{5}{*}{ Opportunity } & Student apartments & 625 & 777.74 & \multirow{5}{*}{19.503} & \multirow{5}{*}{3} & \multirow{5}{*}{0.000} \\
\hline & With their families & 270 & 714.57 & & & \\
\hline & Government dormitories & 450 & 752.07 & & & \\
\hline & Private dormitories/pensions & 200 & 884.16 & & & \\
\hline & Total & 1545 & & & & \\
\hline \multirow{5}{*}{ Economy } & Student apartments & 375 & 465.32 & \multirow{5}{*}{1.167} & \multirow{5}{*}{3} & \multirow{5}{*}{0.761} \\
\hline & With their families & 162 & 477.88 & & & \\
\hline & Government dormitories & 270 & 461.98 & & & \\
\hline & Private dormitories/pensions & 120 & 445.69 & & & \\
\hline & Total & 927 & & & & \\
\hline
\end{tabular}




\section{Conclusions}

The choices of the students who were registered in the Faculty of Economics and Administrative Sciences of Kafkas University in 2013-2014 term were investigated in order to determine the factors affecting university choices. At the end of this investigation, it is possible to put the factors affecting the student's university choices in order under six topics as prestige, opportunity, campus, knowledge, location, and economy.

In the factor analysis that was carried out to 309 surveys in the scope of the research, KMO ratio was calculated as 0.833, Bartlett's test value was calculated as 3218.608 ( $\mathrm{p}<0.000)$ and these data were found to be appropriate for factor analysis and they were collected under six factors that explain $59.516 \%$ of the total variance. Then Cronbach's Alpha test was applied to these factors and the results that were obtained have come out to be confident. In Mann-Whitney U Test that was carried out in order to establish the averages of male and female students in their factor preferences, whereas a statistically significant difference was established in the student's university choices in location and opportunity factors according to their sex, a significant difference was not established according to their sex in the other factors.

The results of Kruskal-Wallis test that was used in order to establish whether there is a statistically significant difference between the averages of the demographic characteristics in the factors are as follows. In the analysis that was carried out in the students' university choices according to their fathers' occupations, the difference between the averages in location factor was found to be significant. In the analysis that was carried out according to the monthly income of the student's family, the difference has come out to be statistically significant in prestige, knowledge, and opportunity factors. In the analysis that was carried out according to the student's monthly expenses, a significant difference was established in prestige, knowledge, location, and economy factor. In the analysis that was carried out according to the geographical region that the student comes from, it was understood that there was a significant difference between prestige, campus, location, and opportunity factors. In the analysis that was carried out according to the place of residence of the student's family, it was found that there is a significant difference between the averages in prestige, knowledge, campus, and location factors and lastly, in the analysis that was carried out according to the place of residence in the city where the student studies, a significant difference was found between the averages in prestige, campus, location, and opportunity factors.

Besides, when the order average values of the students about their demographic characteristics are considered, whereas there is the strongest participation ratio in the prestige factor in the university choices of female and male students, this is followed by opportunity, campus, knowledge, economy, and location factors respectively. When the averages about the father's occupation are taken into consideration, the students whose fathers are unemployed put more importance into prestige factor, the students whose fathers are retired put more importance into knowledge, campus, and opportunity factors, the students whose fathers are farmers put more importance into location factor, and the students whose fathers have their own independent businesses put more importance into economy factor. When the values about their families' income are considered, it was established that the level of importance of prestige and knowledge factors were stronger for the students whose families' monthly income is between 1001 - 1500 TL, that of campus factor was stronger for the students whose families' monthly income is above $3000 \mathrm{TL}$, that of location factor was stronger for the students whose families' monthly income is between 2000 - 3000 TL, that of opportunity and economy factors was stronger for the students whose families' monthly income is 500 TL. According to their own monthly expenses, the students whose monthly expenses are between 751 - 900 TL put more importance into prestige, campus, location, and opportunity factors, the students whose monthly expenses are between 901 - 1000 TL put more importance into knowledge factor, and the students whose monthly expenses are between 501 - 750 TL put more importance into economy factor. When the geographical region that the student is coming from is considered, it was established that the participation ratio of the students coming from Aegean region was stronger in prestige, campus, and opportunity factors, that of the students coming from Black Sea region was stronger in knowledge factor, that of the students coming from Eastern Anatolian region was stronger in location factor, and that of the students coming from Middle Anatolian region was stronger in economy factor. When the averages about their families' places of residence are considered, it was established that a stronger participation was maintained in prestige, knowledge, and opportunity factors by the students whose families live in counties, in the campus factor by the students whose families live in metropolitan municipalities, and in location and economy factors by the students whose families live in cities that are not metropolitan municipalities. Another result that comes out in the table is the values belonging to the order averages of the groups. When the student's place of residence in the city that the 
student studies in is considered, it was found that a stronger participation was maintained in prestige, campus, and opportunity factors by the students who stay in private dormitories or pensions, in knowledge and location factors by the students who stay in government dormitories, in economy factor by the students who stay with their families.

Lastly, when the data obtained at the end of all of the statistical analyses that were carried out in this study are evaluated, it can be said that the students show differences in their participation in the factors that are effective on their university choices according to certain demographic characteristics and in this way a summary about the student's university choices has emerged. In this sense, it can be said that if the universities know which factors are effective in the university choices of the students who will begin their higher education and if they improve themselves by making appropriate strategical plans according to the results that emerge in this study and if they have an enterprising and innovative spirit, they will be chosen more by the candidate students.

This study includes the Kafkas University students at the Faculty of Economics and Administrative Sciences. Therefore, the results of research should be considered these limitations. Researchers who want to work on this issue in the future, they are able to make comparisons between different departments and regions.

\section{References}

[1] Koçel, T. (2003) Business Administration: Management and Organization, Behavior in Organizations, Modern-Contemporary Classical and Contemporary Approaches. 9th Press, Beta Printing Publishing Distribution Inc., İstanbul.

[2] Lakhal, S., Frenette, E., Sevigny, S. and Khechine, H. (2012) Relationship Between Choice of a Business Major Type (Thing-Oriented versus Person-Oriented) and Big Five personality Traits. The International Journal of Management Education, 10, 88-100. http://dx.doi.org/10.1016/j.ijme.2012.03.003

[3] Green, L. and Celkan, G. (2014) A Very Crucial Turning Point in One’s Life: College/University Choice. ProcediaSocial and Behavioral Sciences, 116, 990-995. http://dx.doi.org/10.1016/j.sbspro.2014.01.333

[4] http://www.tubitak.gov.tr/tr/haber/turkiyenin-girisimci-ve-yenilikci-50-universitesi-aciklandi

[5] http://www.yok.gov.tr/web/guest/universitelerimiz,26.12.2014

[6] Horstschraer, J. (2012) University Rankings in Action? The Importance of Rankings and an Excellence Competition for University Choice of High-ability Students. Economics of Education Review, 31, 1162-1176. http://dx.doi.org/10.1016/j.econedurev.2012.07.018

[7] Sathapornvajana, S. and Watanapa, B. (2012) Factors Affecting Student's Intention to Choose IT Program. Procedia Computer Science, 13, 60-67. http://dx.doi.org/10.1016/j.procs.2012.09.114

[8] Akar, C. (2012) Factors Affecting University Preference: A Study on the Students of Economics and Administrative Sciences. Eskişehir Osmangazi University IIBF Journal, 7, 97-120.

[9] Sarpkaya, R. (2010) Individual Education Claims Affecting the University Entrance: Adnan Menderes University Case, Educational Sciences: Theory \& Practice, 10, 449-488.

[10] Günay, D. (2004) Essence of the University, Academic Freedom and University Autonomy. International Congress on Higher Education, İstanbul, May 27-29.

[11] Zhou, J.P. (2014) From Better Understandings to Proactive Actions: Housing Location and Commuting Mode Choices among University Students. Transport Policy, 33, 166-175. http://dx.doi.org/10.1016/j.tranpol.2014.03.004

[12] Zhou, J.P. (2012) Sustainable Commute in a Car-dominant City: Factors Affecting Alternative Mode Choices among University Students. Transportation Research Part A, 46, 1013-1029. http://dx.doi.org/10.1016/j.tra.2012.04.001

[13] Ercan, İ. and Kan, İ. (2004) Reliability and Validity in Scales. Uludağ Universiy Journal of College of Medicine, 30, 211-216.

[14] Türkan, Y.S., Manisali, E. and Çelikkol, M.F. (2009) Analysis of Critical Success Factors Affecting Six Sigma Project Success of Turkish Manufacturing Sector. Journal of Engineering and Natural Sciences, 7, 105-117.

[15] Demirgil, H. and Kalayci, Ş. (2010) SPSS Applied Multivariate Statistical Techniques. 5th Press, Asil Printing Publishing Distribution, Ankara. 